\title{
State of the Art in Precoated Steel Sheet for Automotive Body Materials in Japan
}

\author{
Yasuhiko MIYOSHI
}

Surface Treatment Research Laboratory, R \& D Laboratories-II, Nippon Steel Corporation, Shintomi, Futtsu, Chiba-ken, 299-12 Japan.

(Received on April 13, 1990; accepted in the final form on June 29, 1990)

\begin{abstract}
The history of precoated steel usage as car body materials in Japan is reviewed first. Japanese steelmakers developed galvannealed steel, duplex $\mathrm{Zn}-\mathrm{Fe}$ coated steel, $\mathrm{Zn}-\mathrm{Ni}$ coated steel and organic composite coated steel. All of them have been widely used. Recently, electrolytically $\mathrm{Fe}-\mathrm{Zn}$ plated galvannealed steel and $1 \mu \mathrm{m}$ thick organic painted $\mathrm{Zn}-\mathrm{Ni}$ electroplated steel have been applied. They have not only excellent corrosion resistance, but alsc good paintability, formability and weldability. Car body corrosion is classified into cosmetic corrosion and perforation. Newly clarified mechanisms for these two are explained. As for current research subjects, the development of inorganic and organic dispersion coating, $\mathrm{Zn}-\mathrm{Mn}$ plating, galvannealed steel by vapor deposition, and vapor phase deposited $\mathrm{Zn}-\mathrm{Mg}$ coating are described. Surface roughness control, application to vibration damping sheet, adhesive bonding, and the adaptation to lightweight cars are also important subjects to be studied now.
\end{abstract}

KEY WORDS: precoated steel; automobile; corrosion resistance; paintability; formability; weldability; image clarity; adhesive bonding; lightweight car.

\section{Introduction}

Many authors ${ }^{1-4)}$ have already published reviews on precoated steel sheets for automotive use in Japan. Since then, the technology of corrosion protection has made steady progress. Good corrosion resistance is now one of a car's strong selling points. The percentage of precoated sheet panels used in a body-inwhite is now estimated as 60-90\% for export cars and about $40 \%$ for domestic cars, and it is increasing. In the future, all panels of export cars will be precoated except for the roof. Some European manufacturers are producing good corrosion resistant cars with $100 \%$ Zn-plated panels.

In Japan, more than 10 million metric tons of $\mathrm{Zn}$ plated steel sheet are produced in a year. Of that total, in 1988, about 2.3 million tons were for automotive use. Pure $\mathrm{Zn}$ plated-, $\mathrm{Zn}-\mathrm{Fe}$ alloy coated-, $\mathrm{Zn}-$ $\mathrm{Ni}$ alloy coated- and organic composite coated steels are 4 main kinds.

In this paper, the history of automotive steel usage is first overviewed. Then the corrosion mechanism of car bodies, the classification and performance of precoated steels, research in this field and future trends will be reviewed, especially concentrating on corrosion problems. Corrosion is caused by de-icing salt, marine atmosphere and acid rain. Among these, de-icing salt is the most important and has been the most precisely studied.

\section{History of Precoated Steels for Automotive Bodies}

Fig. 1 shows the secular change of precoated steels used for car bodies. The use of de-icing salt in North America and Canada increased very rapidly from 1950 to 1970. As a result, the corrosion of car bodies was actualized around 1960 in these regions. In the early 1960's American car manufacturers started to apply $\mathrm{Zn}$ coated steel sheets for from-theoutside unvisible body parts, such as floor, in order to suppress corrosion. Since 1963, when the hot dip galvanized rocker panel showed an excellent durability, $\mathrm{Zn}$ plated sheets have been used as visible part panels, such as doors and fenders. In 1972, the application of Zincro Metal (zinc chromated and Zn rich primed sheet) began.

In Japan, with the increase of car exports to North America, automobile manufacturers developed considerable interest in the corrosion problem. Electrogalvanized steel was applied first in 1974 for the bodyin-white of an export car. In 1977, a steelmaker developed galvannealed sheet with a good performance and started to supply it for body panels.

In 1978, the Canadian Government introduced the famous Canadian Code, which is an anticorrosion code establishing minimum levels of corrosion protection to be provided for all vehicles sold in Canada. Japanese car manufacturers were forced to design export vehicles which fulfill the requirements of the Canadian Code, because the United States also observed the Code. They raised the amount of precoated steels to be used in body-in-white rapidly around 1980, for example $47 \%$ for export cars and $16 \%$ for domestic cars in 1982.5) In 1983, a more severe Scandinavian Code was introduced in Europe, which required 3 years cosmetic corrosion free and 6 years perforation free. 


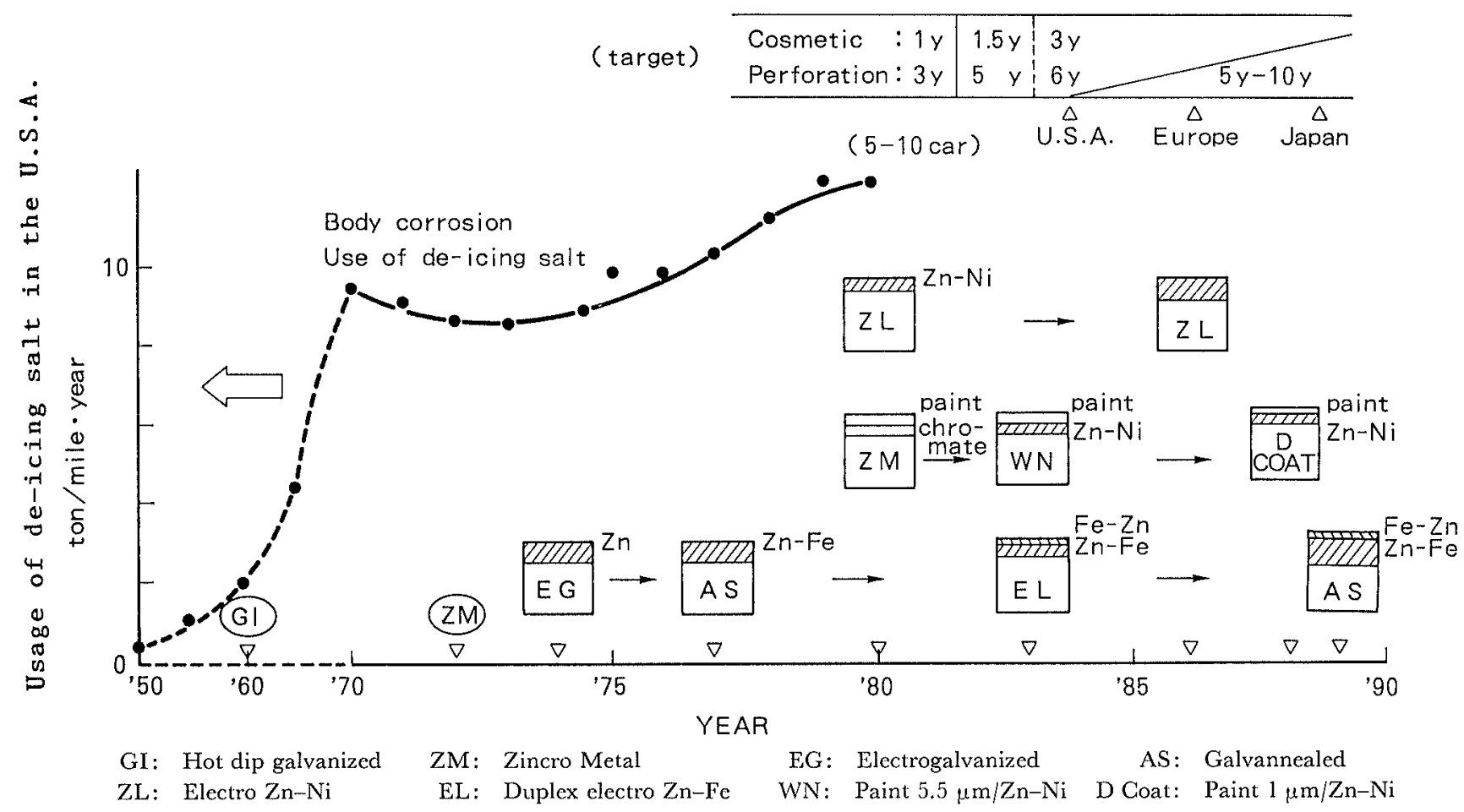

Fig. 1. History of precoated stecl application to automobiles in Japan.

In accordance with the above-mentioned situation, Japanese steel manufacturers made great efforts to develop new precoated steels having higher performances than the ones being used at that time. Three different kinds were invented by refining the longstanding galvanized steel and/or Zincro Metal. They are: duplex $\mathrm{Zn}-\mathrm{Fe}$ alloy electroplated steel $\left(20 \mathrm{~g} / \mathrm{m}^{2}+\right.$ $\left.3 \mathrm{~g} / \mathrm{m}^{2}\right), \mathrm{Zn}-\mathrm{Ni}$ alloy electroplated steel $\left(20-30 \mathrm{~g} / \mathrm{m}^{2}\right)$, and organic composite coated steel $(\mathrm{Zn}-\mathrm{Ni}$ base, 15 $\left.\mathrm{g} / \mathrm{m}^{2}\right)$. They not only have an excellent corrosion resistance but also good press formability and weldability. Moreover, they are not too expensive.

About the middle of the 1980's, American automakers prolonged the target years of corrosion-free to 10-5, which means 10 years of perforation free, 5 years of cosmetic corrosion free. They tried to improve corrosion resistance by using a lot of $\mathrm{Zn}$ coated steel. In 1984, at the SAE (Society of Automotive Engineers) Exposition, Chrysler made public its T-Wagon whose body-in-white was made of hot dip galvanized steels except for the roof. The percentage of galvanized steel reached $88 \%{ }^{6}$ ) Influenced by this technical trend, Japanese automakers gradually increased the usage of precoated steel. The coating weight of the $\mathrm{Zn}$ or $\mathrm{Zn}$-alloy layer was also increased.

In 1989, several Japanese automakers made public their 10-5 cars by applying either galvannealed steel with $60 \mathrm{~g} / \mathrm{m}^{2}$ or organic composite coated steel with $30 \mathrm{~g} / \mathrm{m}^{2}$ of $\mathrm{Zn}-\mathrm{Ni}$. However, they are not fully satisfied with these materials. Work toward improvement is underway among steelmakers.

\section{Corrosion Mechanism of Car Bodies}

\subsection{General}

Car body corrosion is caused by de-icing salt, ma- rine atmosphere and acid rain. Among these three factors, de-icing salt is the most influencial and has been widely studied.

Corrosion is classified into two main categories, cosmetic type and perforation. The former means red rust formation, paint blistering and delamination of visible parts, all of which start from paint damage or defects. The latter means penetration of panels, which often occurs at the hemming part of assembled panels.

Previous papers discussed corrosion mechanism in general..$^{3,7-10)}$ In this paper, newly obtained results will be explained.

\subsection{Cosmetic Corrosion}

These days both-side zinc coated steel is generally used for body outer panels. If the outside paint film has been damaged during car driving, underfilm corrosion starts from the paint defect and propagates under the paint film. As zinc is a less noble metal compared with iron, it is attacked preferentially at an early stage and, as a result, a corrosion layer develops parallel to the surface, as is shown in Fig. 2.

Oxygen is supplied through the paint defect and a local cell is formed, where the corrosion front acts as an anode and the substrate near the paint defect acts as a cathode. ${ }^{8,11,12}$ The corrosion mechanism is shown in Fig. 3.11) At the extreme front, zinc is oxidized in the anodic reaction and becomes zinc chloride. ${ }^{13)}$ Then it is converted into zinc hydroxide or oxide. After the metallic zinc has been consumed, the steel substrate begins to have an anodic reaction. As iron corrosion product is larger in volume than metallic iron, a volume increase occurs, which lifts up the paint and results in blistering or delamination. 


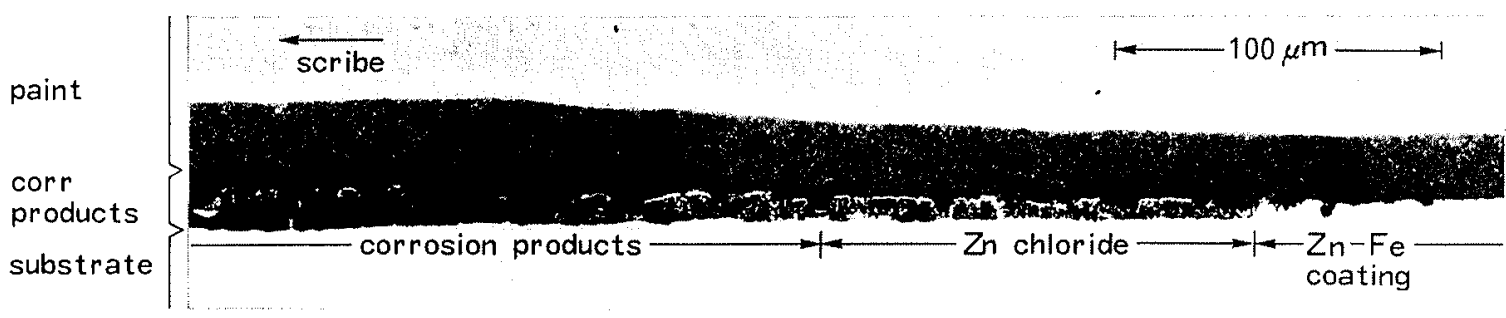

Fig. 2. Microscopic observation of paint blistering of galvannealed steel after a half year weathering test with $5 \% \mathrm{NaCl}$ solution spray once a day except for weekend.

Fig. 3.

Mechanism of underfilm corrosion for painted $\mathrm{Zn}$ coated steel. ${ }^{11}$

\subsection{Perforation}

Perforation is often observed at the hemming part of assembled panels, such as doors, hoods and quarter panels. A hem has a small gap, which is very diffcult to be covered with paint. And moreover, if water penetrates, it stays for a long period.

Cross sections of corroded door hems from a 10 year field-drive car are shown in Fig. 4.14) There are 4 remarkable points.

(a) The outer panel, not the inner panel, gets perforated.

(b) Perforation progresses from inside to outside.

(c) Corrosive substances are supposed to come to the gap not only from the top but also from the hem edge.

(d) The gap becomes wider because of rust growth.

From these points, the perforation mechanism of a door hem can be estimated as follows:

\section{(1) Initiation}

Water and salt are supplied from the window glass etc., to the gap. If adhesive, inner sealer or wax is insufficient, they stay there and start corrosion. Or, the hem edge is first attacked and corrosive substances reach the gap through it.

\section{(2) Propagation}

The gap surface, where paint thickness is zero or small, becomes easily corroded. Because of the temperature difference between the atmosphere and the gap inside, the outer panel surface dries up much slower than the inner panel surface, and dewing may even occur. Therefore, the former is attacked much faster than the latter.

\section{(3) Perforation}

Once a hole has been formed in the outer panel, corrosive substances are supplied through that hole
$\mathrm{Cl}^{-}, \mathrm{H}_{2} \mathrm{O}_{2}, \mathrm{O}_{2}$

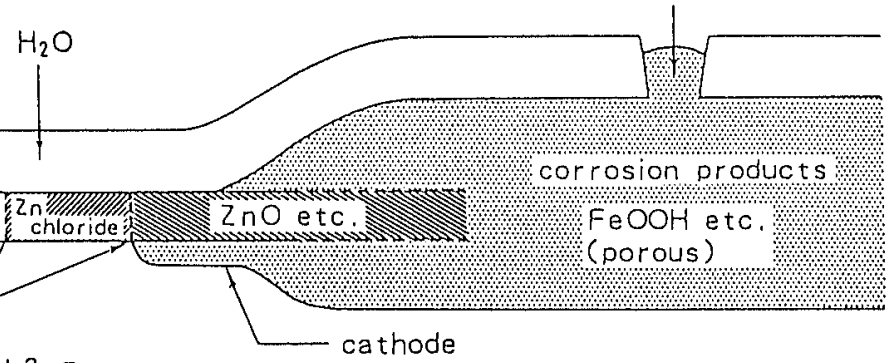

$$
\mathrm{Fe}^{2+}+2 \mathrm{OH}^{-}+\mathrm{Fe}(\mathrm{OH})_{2}
$$
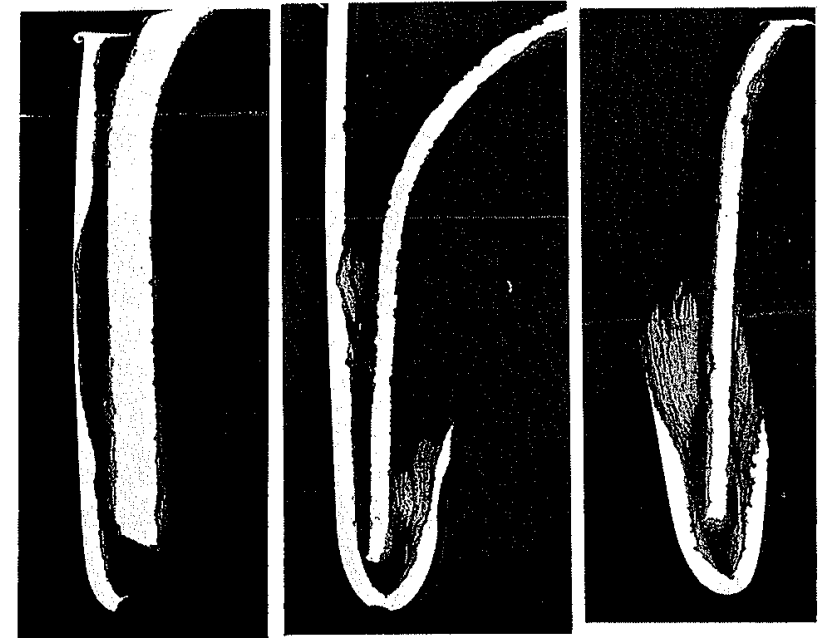

Fig. 4. Cross-sectional observations of corroded door hems from a 10-year field drive car. ${ }^{14}$ ) Three different positions from one door were investigated.

and it will grow quickly in size.

(4) Deformation

Rust growth deforms the hem.

\section{Glassification of Precoated Steels for Car Body}

Precoated steels can be classified into 4 categories: hot dipped, hot dipped \& electroplated, electroplated, and electroplated \& painted. Table 1 gives the summary of these steels being properly used for car bodies. In Table 1, hot dipped \& electroplated steel and electroplated \& $1 \mu \mathrm{m}$ thick painted steel, have been recently put into practical use. 
ISIJ International, Vol. 31 (1991), No. 1.

Table 1. Precoated steel being properly used for car body in Japan.

\begin{tabular}{|c|c|c|c|}
\hline Category & Designation & Precoat layer & $\begin{array}{c}\text { Coating weight } \\
\text { ( } \mathrm{g} / \mathrm{m}^{2} \text { per one side) }\end{array}$ \\
\hline \multirow{2}{*}{ Hot dipped } & Pure $\mathrm{Zn}$ & $\mathrm{Zn}$ & $60-120$ \\
\hline & Galvannealed & $\mathrm{Zn}-\mathrm{Fe}$ & $30-90$ \\
\hline Hot dipped \& electroplated & Duplex & $\mathrm{Fe}-15 \mathrm{Zn} / \mathrm{Zn}-\mathrm{Fe}, \mathrm{Fe}-\mathrm{P} / \mathrm{Zn}-\mathrm{Fe}$ & $3 / 45-90$ \\
\hline \multirow{3}{*}{ Electroplated } & Pure $\mathrm{Zn}$ & $\mathrm{Zn}$ & $10-30$ \\
\hline & Duplex $\mathrm{Zn}-\mathrm{Fe}$ & $\mathrm{Fe}-15 \mathrm{Zn} / \mathrm{Zn}-15 \mathrm{Fe}$ & $3 / 20$ \\
\hline & $\mathrm{Zn}-\mathrm{Ni}$ & $\mathrm{Zn}-11 \mathrm{Ni}$ & $20-40$ \\
\hline \multirow{2}{*}{ Electroplated \& painted } & Organic composite & Organic film/Zn-11Ni & $1 \mu \mathrm{m} / 20-30$ \\
\hline & Organic composite & Organic film $/ \mathrm{Zn}-11 \mathrm{Ni}$ & $5.5 \mu \mathrm{m} / 15$ \\
\hline
\end{tabular}

\section{Performances of Precoated Steels}

\subsection{Corrosion Resistance}

\subsubsection{Cosmetic Corrosion}

As a car body is exposed to the environments of salt, high humidity, drying, freezing, etc., in the field, corrosion test is usually carried out in cyclic conditions (CGT). Many kinds of CGT have been proposed. ${ }^{3)}$ Principally, CGT is a combination of salt spray and repetition of wet \& dry. One example of CCT is given in Table 2.3)

Figs. 5 and 6 show the effect of zinc or zinc alloy coating weight on the red rust onset and the underfilm corrosion resistance, respectively. ${ }^{15)}$ The increase in coating weight improves both resistances remarkably.

Zinc alloy composition also influences the underfilm corrosion, as is seen in Fig. 7. ${ }^{16}$ ) $\mathrm{Zn}-\mathrm{Fe}$ deposits with $5-15 \% \mathrm{Fe}$ demonstrate the best performance among $\mathrm{Zn}-\mathrm{Fe}$ alloys. This is one reason why $\mathrm{Zn}-\mathrm{Fe}$ coated steels used for car bodies have $8-15 \% \mathrm{Fe}$.

\subsubsection{Perforation}

Perforation is mainly found at the lapped part of a hem. Therefore, the corrosion test is often carried out in CGT using lapped-panel specimens. Fig. 8 shows the result of such an experiment. ${ }^{16)}$ Zinc or $\mathrm{Zn}$ alloy coated steel with a higher coating weight gives a better performance. These days, automakers are changing to a higher coating weight than before in order to achieve long car service life.

As shown in Figs. $9^{17)}$ and $10^{18)}$, alloy composition also has some effect. Considered from these figures, $10-20 \% \mathrm{Fe}$ and $11-13 \% \mathrm{Ni}$, respectively, are the most suitable regions. $\mathrm{Zn}$ alloy coated steels with these compositions are now widely used.

Organic composite coated steel with $\mathrm{Zn}-\mathrm{Ni}$ layer and $1 \mu \mathrm{m}$ thick organic film demonstrates an excellent corrosion resistance before painting. Test results are given in Fig. 11.19) This type of steel is also applied in Japan.

\subsubsection{Gratering Property}

In a car production line, assembled bodies are cathodically electroprimed (G-ED). Depending upon the priming conditions, G-ED film gets a lot of point defects called craters. These craters not only damage the surface appearance, but also cause corrosion. Therefore they are to be avoided.
Tabie 2. One example of GCT (Cyclic Corrosion Test) conditions. ${ }^{3 /}$

\begin{tabular}{cll}
$\rightarrow$ Salt spray & $35^{\circ} \mathrm{C}$ & $4 \mathrm{~h}$ \\
$\downarrow$ & $70^{\circ} \mathrm{C}$ & $2 \mathrm{~h}$ \\
Drying & $\mathrm{RH} 60 \%$ & \\
$\downarrow$ & $49^{\circ} \mathrm{C}$ & $2 \mathrm{~h}$ \\
Humidifying & $\mathrm{RH} 95 \%$ & \\
$\downarrow$ & $-20^{\circ} \mathrm{C}$ & $1 \mathrm{~h}$ \\
Freezing & & \\
\hline
\end{tabular}

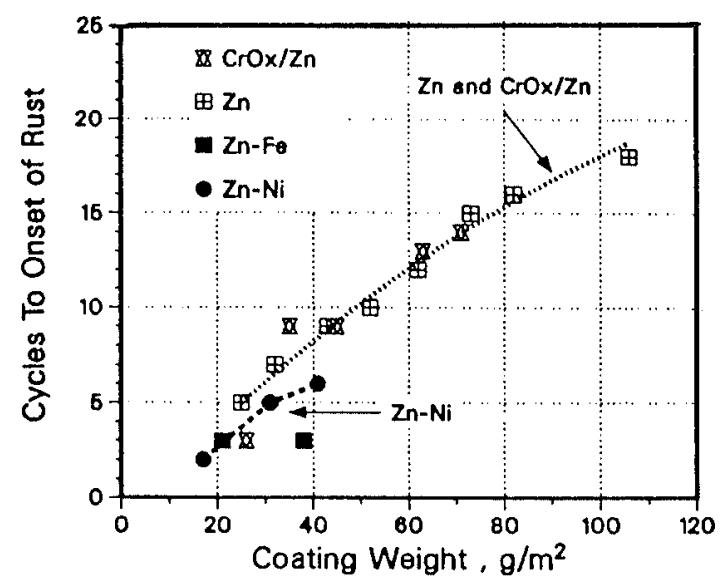

Fig. 5. Relationship between time to onset of red rust at the scribe and the coating weight of unpainted steels in a laboratory cyclic test. ${ }^{\text {i5 }}$

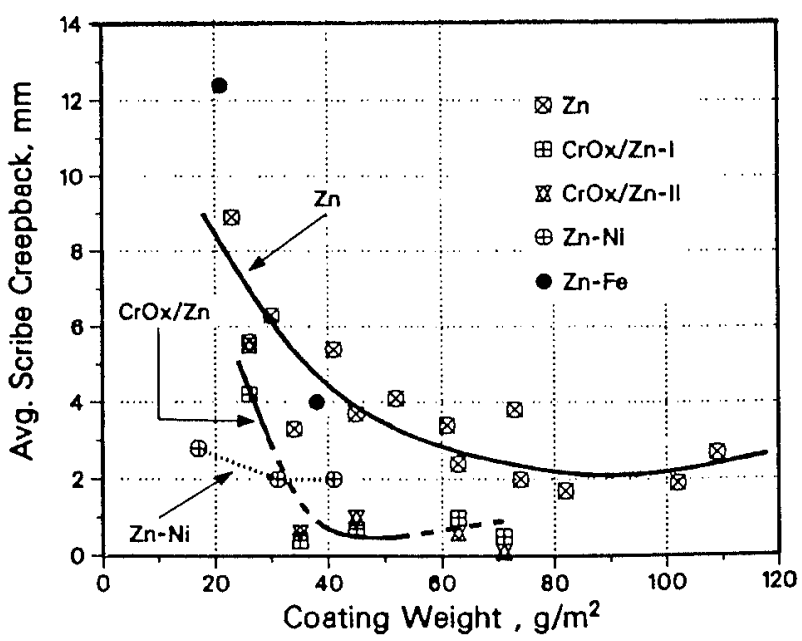

Fig. 6. Influence of the coating weight on the underfilm corrosion in a laboratory test for 30 cycles. $^{15}$, 


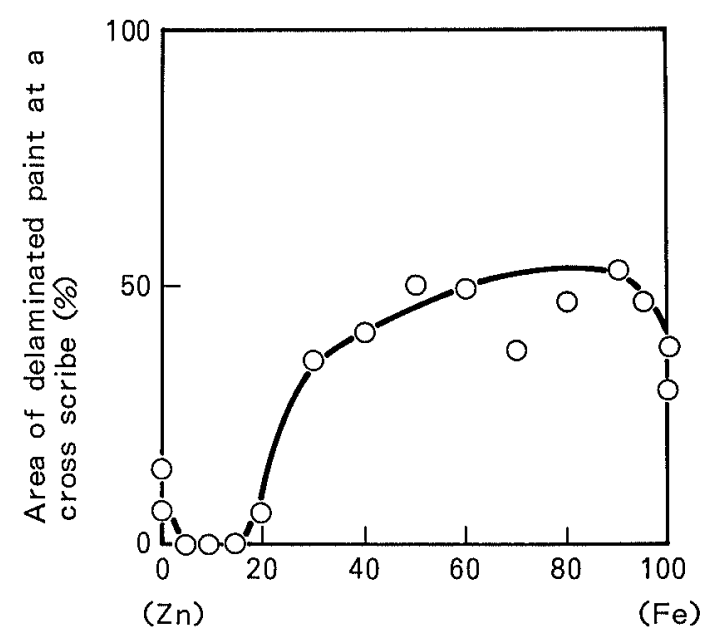

$\mathrm{Fe}$ content of $\mathrm{Zn}-\mathrm{Fe}$ electrodeposit (\%)

Fig. 7. Paint adhesion of $\mathrm{Zn}-\mathrm{Fe}$ electroplated steels in CCT for 4 weeks. ${ }^{10)}$

Specimens were cathodically electropainted and cross scribed.

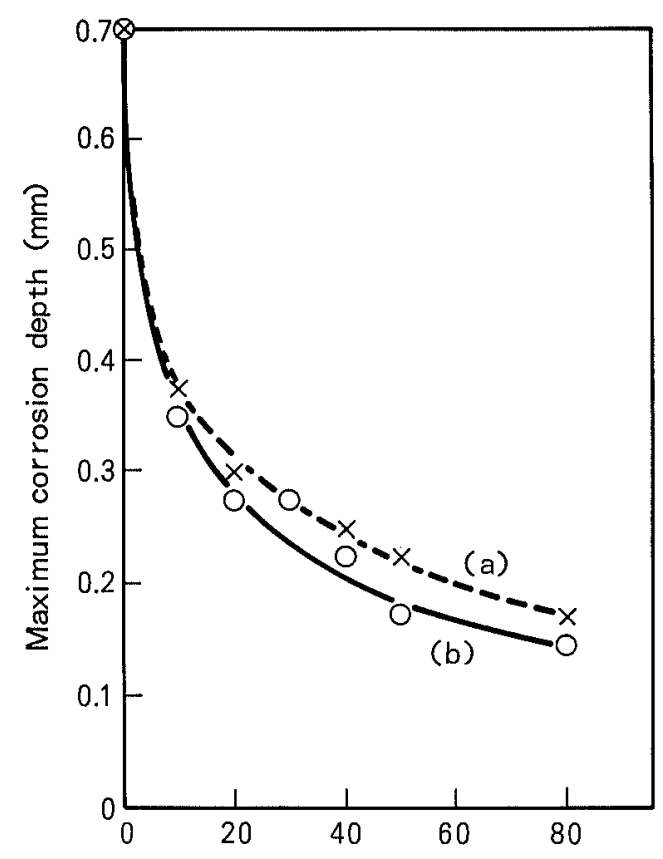

$\mathrm{Zn}$ or $\mathrm{Zn}-\mathrm{Fe}$ Alloy coating weight $\left(\mathrm{g} / \mathrm{m}^{2}\right)$

Fig. 8. Perforation corrosion resistance of electro galvanized steel(a) and $\mathrm{Zn}-15 \% \mathrm{Fe}$ electroplated steel(b) with various coating weights in CCT for 84 cycles. ${ }^{16}$ ) Lapped panel specimens were used.

As is shown in Fig. 12, $\mathrm{Zn}-\mathrm{Fe}$ coatings with low $\mathrm{Fe}$ content are apt to get cratering, ${ }^{20)}$ and lowering the applied voltage reduces the number of craters. In a priming bath where the electrolysis voltage is low, Zn-low Fe alloy coated steel can be painted without craters. However, the number of such baths is small.

Galvannealed steel, which shows an excellent perforation resistance, has a poor cratering property, as can be estimated from its $\mathrm{Fe}$ content. By covering its surface with an $\mathrm{Fe}-15 \% \mathrm{Zn}$ coat by electroplating, its cratering property has been improved.21) Consequently, its usage has been increasing rapidly among

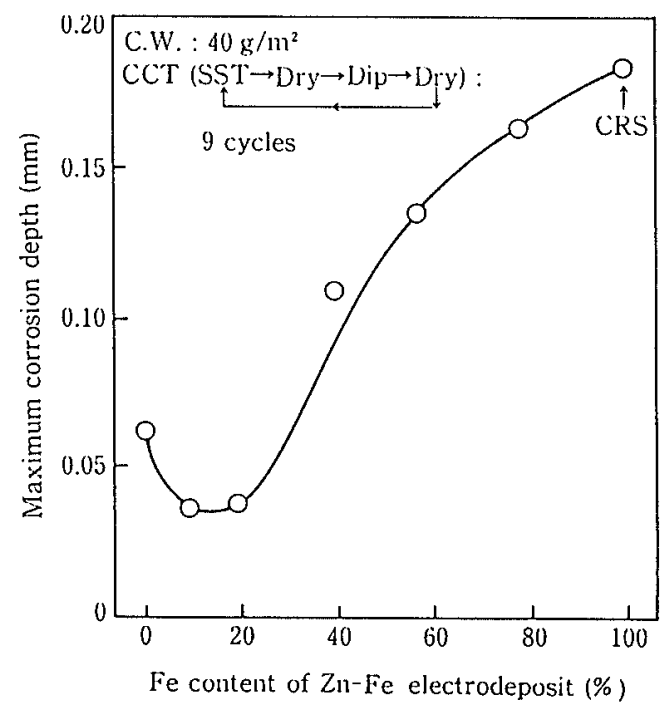

C.W.: Coating weight.

Fig. 9. Influence of $\mathrm{Zn}-\mathrm{Fe}$ alloy composition on the corrosion behavior in a CCT. ${ }^{17)}$

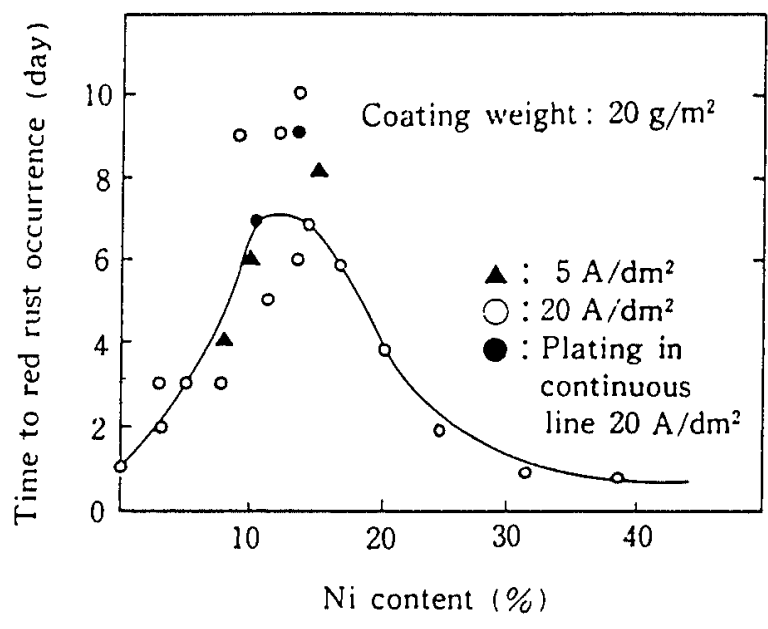

Fig. 10. Influence of $\mathrm{Zn}-\mathrm{Ni}$ alloy composition on the corrosion behavior in salt spray test. ${ }^{131}$

Specimens were prepared under various plating conditions.

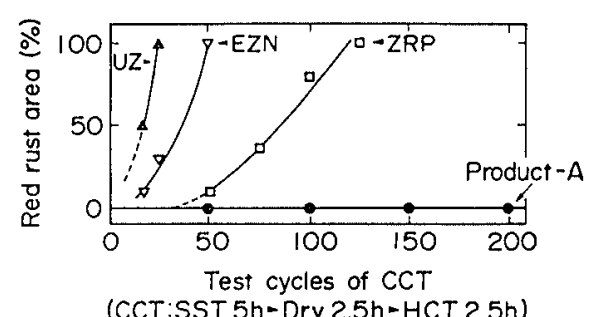

ZRP: Zn-rich painted steel sheet, $15 \mu \mathrm{m}$

EZN: $\quad \mathrm{Zn}-11 \% \mathrm{Ni}$ plated steel sheet, $30 \mathrm{~g} / \mathrm{m}^{2}$

$\mathrm{UZ}$ : Electrogalvanized steel sheet, $70 \mathrm{~g} / \mathrm{m}^{2}$

Fig. 11. Corrosion resistance of organic composite coated steel with $\mathrm{Zn}-\mathrm{Ni}$ layer and $1 \mu \mathrm{m}$ thick organic film (Product-A) in comparison with other steels in a GCT. ${ }^{19)}$

Unpainted specimens were used.

Japanese automakers. In the case of organic composite coating, the organic layer is designed to have no priming defect. 


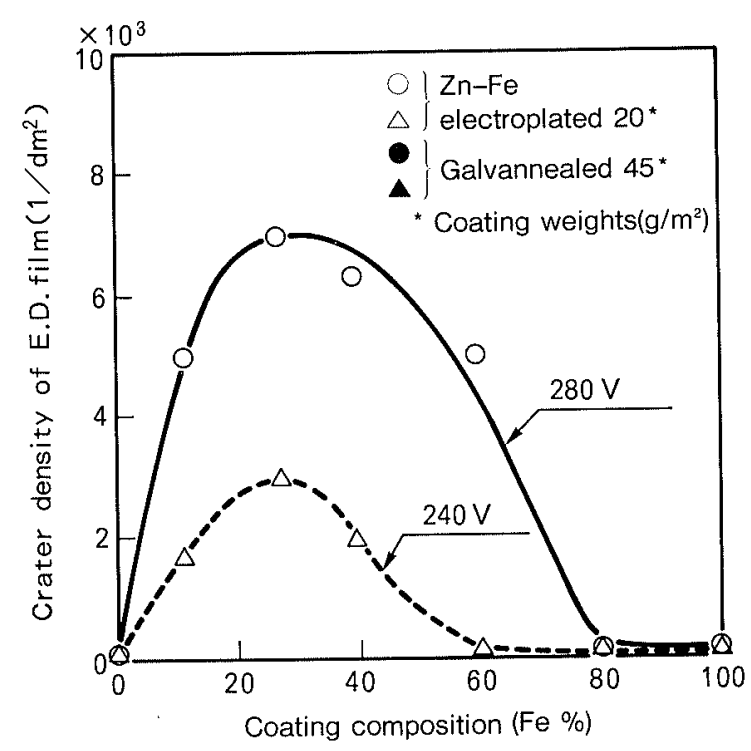

Dip type phosphate: BT 3030

Cathodic E.D. (Conventional epoxy type)

Voltage: 240 and $280 \mathrm{~V}$

Temperature: $28^{\circ} \mathrm{C}$

Electrode distance: $15 \mathrm{~cm}$

Cathode/anode area ratio: $1 / 4$

Fig. 12. Influence of $\mathrm{Zn}-\mathrm{Fe}$ alloy composition on the cratering property. ${ }^{201}$

\subsection{Formability}

\subsubsection{General}

Generally speaking, precoating makes the formability of steel sheet worse. There are two significant aspects. The first is the narrowing of the available range of blank holding force in a press line, due to the deterioration of the mechanical properties of the substrate and to the change of surface lubricity.

The use of Ti- or Nb-added low-C steel as the substrate can avoid the lowering of $r$-value in hot dipping treatment. And the use of lubricants can improve the lubricity.

The second is the exfoliation of precoated materials, such as $\mathrm{Zn}, \mathrm{Zn}$ alloy and organic substances, in a press forming process. The exfoliated materials stick to the dies or punches and cause press defects, called pimples, on the sheet. This phenomenon is called powdering, flaking, or build-up.

Recently, the formability of precoated steels has improved greatly by applying an $\mathrm{Fe}$-rich upper layer or a thin organic film on the top of these steels. In this paper, these new technologies are reviewed.

\subsubsection{Available Range of Blank Holding Force}

Fig. 13 summarizes the results of the press forming tests. ${ }^{22)}$ Three different modes were chosen. They are: stretch forming (hood inner), deep drawing (fender), and severely deep drawing (rear floor). Galvannealed (denoted as GA), galvannealed \& Fe$\mathrm{Zn}$ electroplated (GA with $\mathrm{E}$ ), duplex $\mathrm{Zn}-\mathrm{Fe}$ electroplated (EL) and pure $\mathrm{Zn}$ electroplated steel (EG) were used as specimens.

In the stretch forming mode, no difference was observed between galvannealed steels with 45 and 60

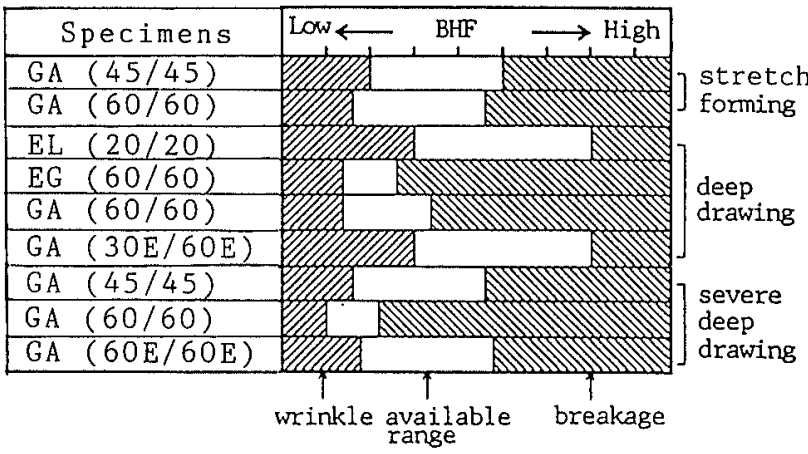

GA: Galvannealed

EL: Duplex electro $\mathrm{Zn}-\mathrm{Fe}$

EG: Electro $Z$ n

$\mathrm{GA}(\mathrm{E})$ : Galvannealed and $\mathrm{Fe}-\mathrm{Zn}$ electro coated BHF: blank holding force

Number in parenthesis: coating weight $\left(\mathrm{g} / \mathrm{m}^{2}\right)$

Fig. 13. Press formability of various steels. ${ }^{22)}$

$\mathrm{g} / \mathrm{m}^{2}$. However, in the drawing mode increasing the coating weight considerably narrowed the available press range. This is thought to be brought about by the change of surface lubricity due to the formation of $\mathrm{Zn}-\mathrm{Fe} \zeta$-phase on the galvannealed surface. ${ }^{23)}$ It is very difficult to avoid the $\zeta$-phase formation in the galvannealing process when the coating weight is high. In the case of pure $\mathrm{Zn}$ electroplated steel, a pure $\mathrm{Zn}$ layer easily sticks to the die or punch and causes problems.

An electroplated $\mathrm{Fe}-\mathrm{Zn}$ layer on the top of galvannealed steel remarkably widens the available press range, as can be seen in Fig. 13. The hard Fe-Zn layer works as a kind of lubricant. Galvannealed \& $\mathrm{Fe}-\mathrm{Zn}$ electroplated steel is now widely used in Japan.

Fig. 14 gives the press formability of $\mathrm{Zn}-\mathrm{Ni}$ electroplated \& $1 \mu \mathrm{m}$ thick organic painted steels (OF-1 to -3) in comparison with other steels. ${ }^{24)}$ Organic composite coated steel (OF) showed almost the same available press range as cold rolled steel (CR). Its formability is better than other precoated ones tested. This type of steel is also often applied in Japan.

\subsubsection{Exfoliation of Coating Layer}

An $\mathrm{Fe}-\mathrm{Zn}$ overlayer on galvannealed steel considerably decreases the pimples caused by flaking, as is shown in Fig. 15. ${ }^{23)}$ It is more effective than other methods such as lubricant 6 cst and wax. This is a result of successive fender pressings.

An organic film on $\mathrm{Zn}-\mathrm{Ni}$ layer has the same effect. Fenders were press formed from various steels and tape peel tested. Fig. 16 gives the results. ${ }^{24)}$ Organic film (OF-1 to -3 ) reduces the coating exfoliation of the $\mathrm{Zn}-\mathrm{Ni}$ layer.

\subsection{Weldability}

In the body assembling process spot-, arc-, gasand laser-welding are applied. Precoated steels have worse weldability than cold rolled steel. There are many reasons for that. Zinc plating needs a large spot welding current, because zinc melts easily and, as a result, widens the nugget diameter. Both zinc and organic film react with the spot welding tip and 
damage it. The Zn layer brings about blow holing in arc welding due to its high vapor pressure.

For the sake of good weldability, a thin precoating

\begin{tabular}{|c|c|c|c|c|c|c|c|c|c|}
\hline Spoci- & \multicolumn{9}{|c|}{8 lank holding force (Ton) } \\
\hline mens & 115 & 120 & 125 & 130 & 135 & 143 & 151 & 159 & 163 \\
\hline CR & & & & & & & & & \\
\hline$O F-1$ & & & & & & & & & \\
\hline$O F-2$ & & & & & & & & & \\
\hline OF -3 & & & & & & & & & \\
\hline $2 n-N i$ & & & & & & & & & \\
\hline $2 n-F_{0}$ & & & & & & & & & \\
\hline EG & & & & & & & & & \\
\hline GA-1 & & & & & & & & & \\
\hline GA-2 & & & & & & & & & \\
\hline
\end{tabular}

Legend : Fracture Wrinkle

$\Delta$ Wave of dieface

CR: Cold rolled

OF-1: $1 \mu \mathrm{m}$ organic/Zn-Ni (30/30)

OF-2: $\quad 1 \mu \mathrm{m} / \mathrm{Zn}-\mathrm{Ni}(20 / 20)$

OF-3: $1 \mu \mathrm{m} / \mathrm{Zn}-\mathrm{Ni}(0 / 20)$

$\mathrm{Zn}-\mathrm{Ni}$ : Electro $\mathrm{Zn}-\mathrm{Ni}(30 / 30)$

$\mathrm{Zn}-\mathrm{Fe}$ : Electro $\mathrm{Zn}-\mathrm{Fe}(40 / 40)$

EG: Electro $\mathrm{Zn}(60 / 60)$

GA-1: Galvannealed (60/60 Fe $9 \%$ )

GA-2: Galvannealed (60/60 Fe $12 \%$ )

Fig. 14. Press formability of various steels. ${ }^{24}$

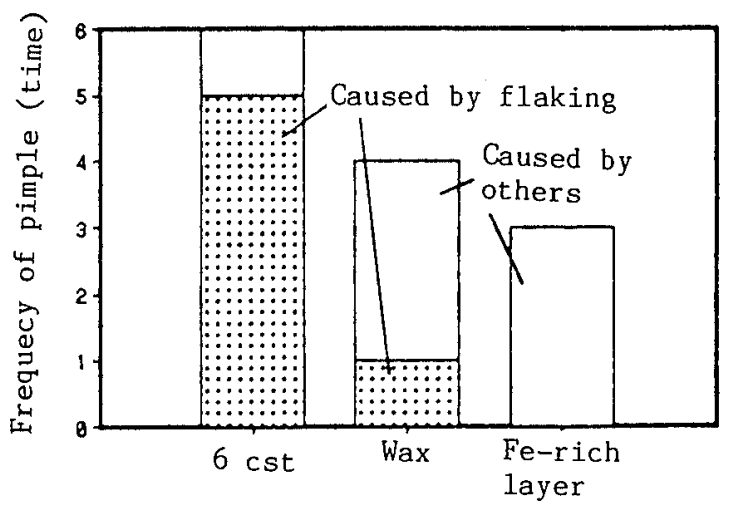

6 cst and wax: Lubricants

Fig. 15. Effect of Fe-rich upper layer on galvannealed steel in decreasing the press pimples caused by flaking. ${ }^{23}$

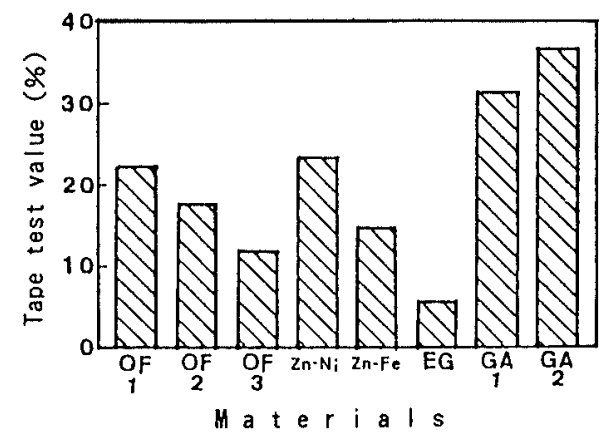

Materials used are the same as in Fig. 14.

Fig. 16. Tape test results for press formed fenders made of various precoated steels. ${ }^{2+1}$ layer is preferable. However, the coating thickness of car body steels has been increasing in order to prolong car service life. Although the existing precoated steels can be welded, automaker engineers are not fully satisfied with their weldability. Efforts must be made to improve it.

\section{Gurrent Research Subjests}

\subsection{Development of New Precoated Steels}

The corrosion resistance of $\mathrm{Zn}$ or $\mathrm{Zn}$ alloy coating can be improved by adding other elements or compounds. Electro-dispersion plating of inorganic substances such as $\mathrm{Al}_{2} \mathrm{O}_{3}, \mathrm{SiO}_{2}$ and $\mathrm{BaCrO}_{4}$ has been carefully studied. ${ }^{25-27)}$ In this process, small particles of such substances are dispersed in $\mathrm{Zn}$ or $\mathrm{Zn}$ alloy plating solutions and electrolysis is carried out. As these particles adsorb ions in the solution on their surface, they migrate to the cathode, discharge electricity of the adsorbed ions and deposit on it together with $\mathrm{Zn}$ or $\mathrm{Zn}$ alloy.

The corrosion behavior of $\mathrm{Zn}-\mathrm{Co}-\mathrm{Cr}-\mathrm{Al}_{2} \mathrm{O}_{3}$ dispersion coated steel is shown in Fig. 17.25) Codeposition of $0.3 \% \mathrm{Al}_{2} \mathrm{O}_{3}$ reduces the thickness loss in salt spray test remarkably. $\mathrm{SiO}_{2}$ and $\mathrm{BaCrO}_{4}$ have the same effect. According to X-ray diffraction measurements, the addition of these substances helps the formation of $\mathrm{ZnCl}_{2} \cdot 4 \mathrm{Zn}(\mathrm{OH})_{2}$, which exerts a corrosion preventive action. ${ }^{28)}$

Zn-organic polymer dispersion coating by electroplating is also studied. The dispersed polymer is said to especially improve paint adhesion. ${ }^{29)}$

$\mathrm{Zn}-\mathrm{Mn}$ coated steel has an excellent corrosion resistance in a salt spray test (SST), as is shown in Fig. 18. ${ }^{30)} \gamma-\mathrm{Mn}_{2} \mathrm{O}_{3}$ is formed in SST, which suppresses the cathodic reaction.

Galvannealed steel can be produced by the zinc vapor deposition process with after-heating. This steel has the same corrosion resistance as that produced by a hot dip method. However, the former

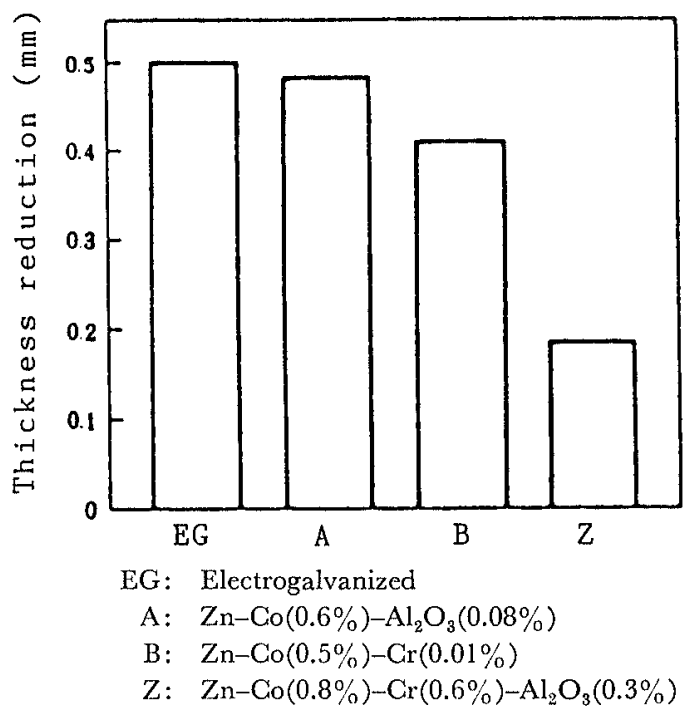

Fig. 17. Corrosion resistance of dispersion coated steels without painting in comparison with other steels in salt spray test for $720 \mathrm{~h}^{25)}$ 


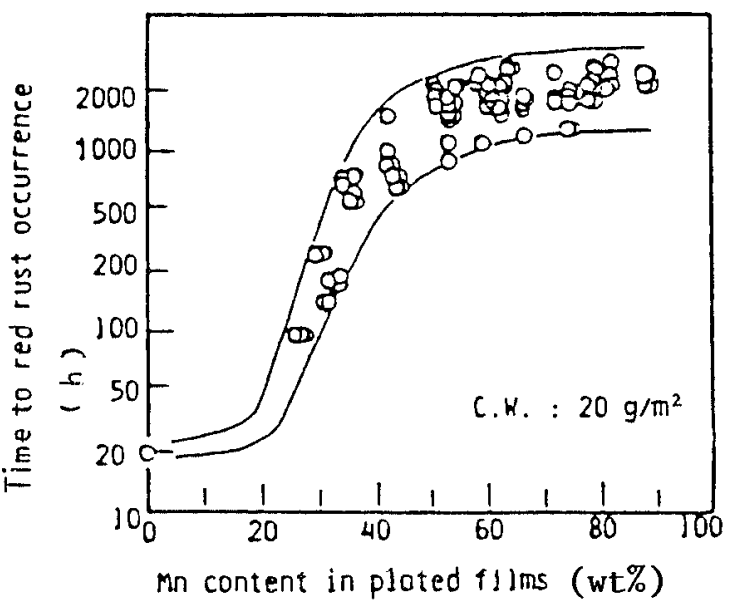

Fig. 18. Corrosion behavior of unpainted various $\mathrm{Zn}-\mathrm{Mn}$ electroplated steels in salt spray test. ${ }^{301}$

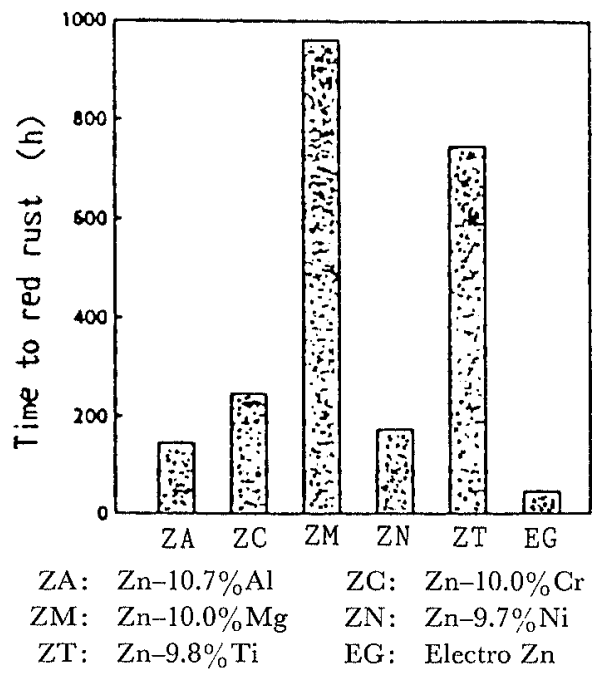

Coating weight: $20 \mathrm{~g} / \mathrm{m}^{2}$ except for $\mathrm{EG}$ which has $40 \mathrm{~g} / \mathrm{m}^{2}$.

Fig. 19. Corrosion behavior of unpainted $\mathrm{Zn}$ alloy vapor deposited steels. ${ }^{32}$ !

shows a much better press formability than the latter. ${ }^{31)}$

Vapor phase deposition enables the preparation of a variety of $Z n$ alloy coatings. Fig. 19 gives the corrosion behaviors of vapor deposited $\mathrm{Zn}-\mathrm{Al}, \mathrm{Zn}-\mathrm{Cr}$, $\mathrm{Zn}-\mathrm{Mg}, \mathrm{Zn}-\mathrm{Ni}$ and $\mathrm{Zn}-\mathrm{Ti}$ coatings. ${ }^{32)}$ Among them, $\mathrm{Zn}-10 \% \mathrm{Mg}$ demonstrates the best performance.

However, none of the above mentioned new $\mathrm{Zn}$ alloy coated steels has been put into practical use, because of either high cost or unsolved problems in mass production.

\subsection{Surface Roughness Control}

There are many factors which determine the value of a car. Recently, image clarity has become one of these important factors. Although the image clarity of a car is determined mainly by the thickness and the quality of the paint, the surface roughness of the substrate steel also exerts a great influence.

The surface roughness is composed of waves with various lengths and intensities. The influence of each

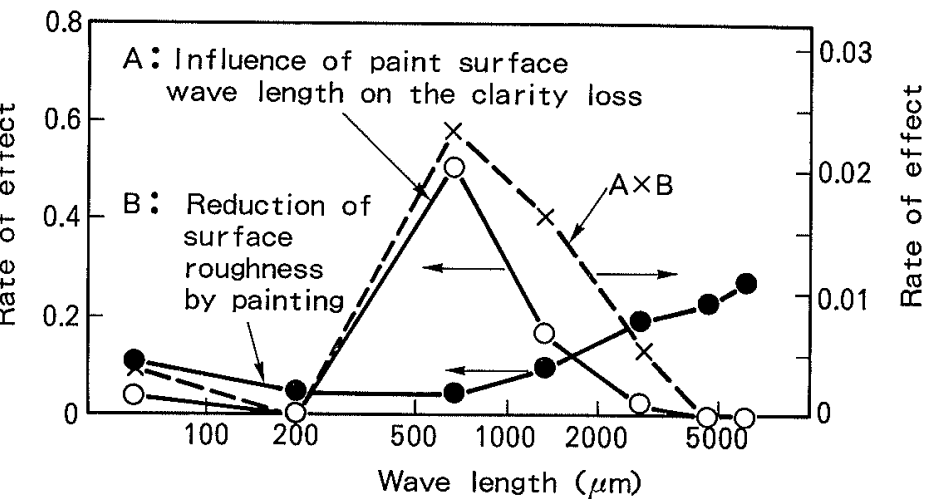

Fig. 20. Influence of steel surface wave length on the image clarity after painting $(\mathrm{A} \times \mathrm{B}) .{ }^{33 \prime}$

wave on the image clarity is given by Fig. 20 which was obtained with the help of Fourier Analysis. ${ }^{33}$ Short length waves are attenuated by painting. Long length ones have little influence on the image clarity. Wave lengths from 500 to $4000 \mu \mathrm{m}$ are important. According to Nishimura et al., the flat area portion of the surface also has to be considered. ${ }^{34)}$

Efforts are being made to reduce the intensity of steel surface waves with 500 to $4000 \mu \mathrm{m}$ of length in order to realize a good image clarity after painting. The surface roughness of precoated steel for outer body panels is controlled by the cold- and skinpass rolling.

\subsection{Vibration Damping Steel Sheet}

Low noise and low vibration of car body are also important factors to determine its value. Vibrationdamping steel, which is made of 2 lapped sheets with a thin resin film between them, has been developed. ${ }^{35)}$ The application of this steel to body panels is well in progress.

Recently, precoated steels have begun to be used as the lapped sheets for the sake of high corrosion resistance. Fig. 21 shows the resin film creepage in CCT (cyclic corrosion test). ${ }^{36}$ ) Vibration-damping steel of GA (galvannealed steel) has a much better performance than that of CR (cold rolled steel).

\subsection{Adhesive Bonding}

Adhesive bonding may be applied to car body assembling in the future more and more, because it can improve body rigidness and fatigue strength. Single lap joints of various $\mathrm{Zn}$ coated steels were constructed using adhesive and the fracturing behaviors of the joints were measured with an Instron-type tensile tester. Results are given in Fig. 22.37)

As the adhesive is a viscoelastic substance, the test temperature has a great influence on the results. Lowering the temperature changes the fracture mode from adhesive type (adhesive/plating interface) to plating type (plating/substrate interface). The plating fracture is not desirable. However, when a test is carried out in a corrosive environment, the adhesive fracture dominates.

Test methods have to be developed which can well simulate field conditions. 


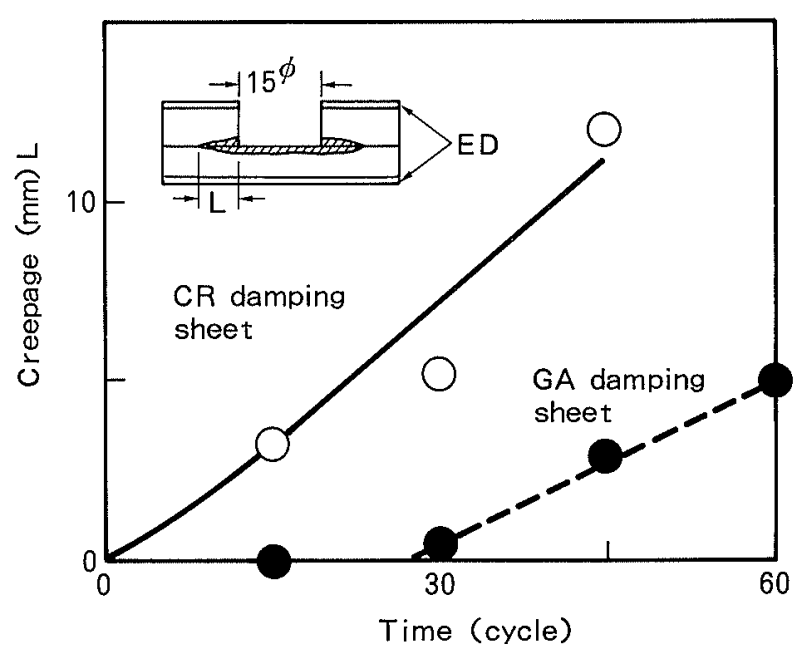

GR: Gold rolled GA: Galvannealed

Fig. 21. Creepage of the sandwiched resin film of vibration damping sheet exposed to CCT. ${ }^{36)}$

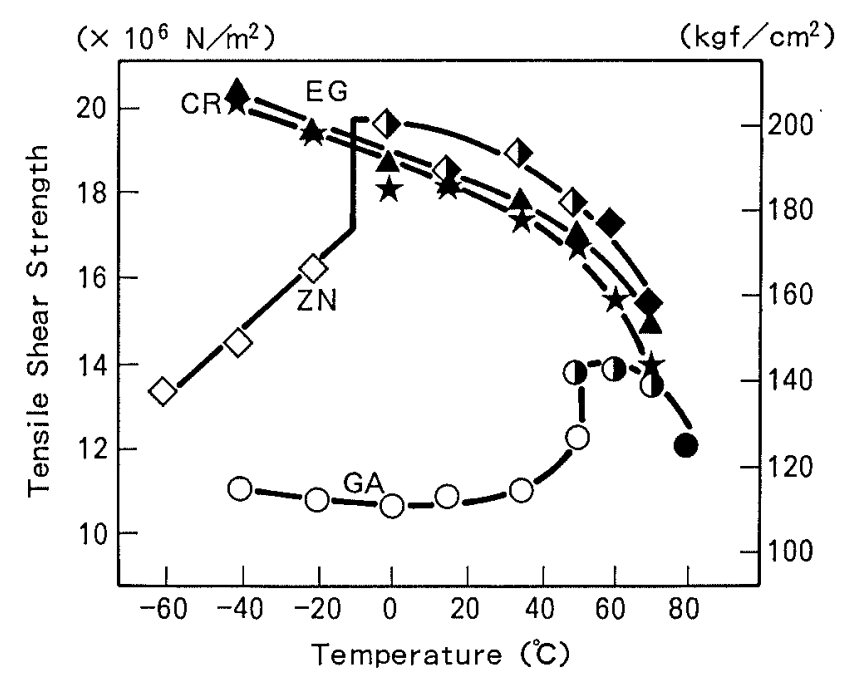

Adherend :

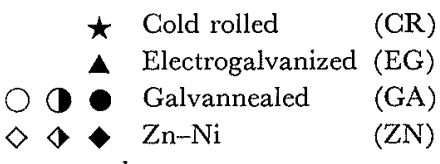

Fracture mode :

$\bigcirc \diamond$ Plating fracture

- Partial plating fracture

$\star \Delta \bullet$ Adhesive fractue

Fig. 22. Influence of test temperature on the fracturing behavior of single lap joints made of various steels. ${ }^{37}$

Test was carried out using an Instron type tensile tester with a crosshead speed of $10 \mathrm{~mm} / \mathrm{min}$.

\subsection{Adaptation to Lightweight Cars}

Currently energy saving is a social demand. In the U.S.A., the Energy Policy Conservation Act was passed by congress and, since 1978, each carmaker has been producing automobiles having given fuel consumption rates in accordance with CAFE (Corporate Average of Fuel Economy). If, in the future, CAFE is changed to a more severe value, carmakers will be forced to develop lightweight cars.

Volvo, from Sweden, designed a concept car, called
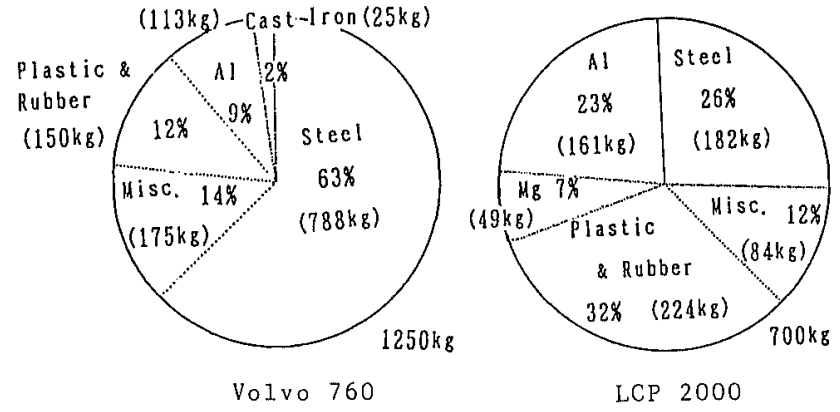

Fig. 23. Component ratio of materials for Volvo cars; the present Volvo 760 and the new concept car LCP 2000.

the LGP 2000, weighing only $700 \mathrm{~kg}$. The weight decrease of $550 \mathrm{~kg}$ is realized in comparison with the present Volvo 760. The component ratio of materials used is shown in Fig. 23. The steel ratio decreases from 63 to $26 \%$. The use of lightweight metals, such as $\mathrm{Al}$ and $\mathrm{Mg}$, and of plastic and rubber has increased. $\mathrm{Al}$ and $\mathrm{Mg}$ may bring about new corrosion problems to precoated steels, especially when they come into an electric contact. A study of this will be necessary in the future.

\section{Conclusion}

Precoated steel was first applied to car bodies in Japan in 1974. Since then galvannealed steel, duplex $\mathrm{Zn}-\mathrm{Fe}$ electroplated steel, $\mathrm{Zn}-\mathrm{Ni}$ electroplated steel and organic composite coated steel have been put into practical use. The percentage of precoated steel in body-in-white has now reached $80 \%$ for some models. In accordance with the 10-5 year corrosion prevention target, two kinds of steels have been newly developed. They are Fe-Zn electrolytically overcoated galvannealed steel with a coating weight of $60-90 \mathrm{~g} / \mathrm{m}^{2}$ and $1 \mu \mathrm{m}$ organic painted $\mathrm{Zn}-\mathrm{Ni}$ electroplated steel with a coating weight of $30 \mathrm{~g} / \mathrm{m}^{2}$. Both show an excellent corrosion resistance, good paintability, good formability and sufficient weldability.

The mechanism of car body corrosion for both cosmetic and perforation types was reviewed.

Efforts to develop new precoated steels are in progress. Inorganic or organic dispersion coating, new $\mathrm{Zn}$ alloy coatings by electroplating or vapor deposition process have several good properties. Surface roughness control, vibration-damping sheet, adhesive bonding and studies concerning lightweight cars are also important research subjects.

\section{REFERENCES}

1) B. Kawasaki: J. Met. Fin. Soc. Jpn., 33 (1982), 440.

2) S. Ishihara: Trans. Iron Steel Inst. Jpn., 23 (1983), 897.

3) M. Kitayama: The 106th-107th Nishiyama Memorial Seminar, ISIJ, Tokyo, (1985), 101.

4) Y. Miyoshi: Corros. Eng. (Jpn.), 35 (1986), 38.

5) K. Sato: Press Working, 22 (1984), No. 12, 64.

6) AISI: STEEL, 1984 SAE Exposition.

7) Y. Miyoshi, M. Kitayama, K. Nishimura and S. Naito: SAE 850007, (1985). 
8) S. Kurokawa, N. Ban, K. Yamamto and T. Ichida: Tetsuto-Hagané, 72 (1986), 1111.

9) N. Shibata and H. Kunimi: Trans. Iron Steel Inst. Jpn., 28 (1988), 578.

10) S. Wakano and M. Nishihara: SAE 890706, (1989).

11) K. Hayashi, Y. Ito and Y. Miyoshi: The Electrochemical Society 174th Meeting, Extended Abstracts, 88-2 (1988), 517.

12) K. Nishimura, Y. Miyoshi and T. Hada: Tetsu-to-Hagané, 73 (1987), 892

13) W. J. van Ooji and T. Jossic: SAE 870674, (1987).

14) Y. Ito and Y. Miyoshi: SAE 892580, (1989).

15) S. G. Fountoulakis and R. N. Steinbicker: Int Gonf. on Zinc and Zinc Alloy Coated Steel Sheet (GALVATECH '89), ISIJ, Tokyo, (1989), 306.

16) Y. Miyoshi, T. Azami, M. Ejima, T. Saito and T. Kanamaru: Seminar STEEL '90, May 7-11, 1990, Genoa, United Nations Economic Commis. Europe, Rep. 1.

17) T. Adaniya, M. Sagiyama and T. Honma: Nippon Kokan Giho, 105 (1984), 82.

18) A. Shibuya, T. Kurimoto, Y. Hoboh and N. Usuki: Trans. Iron Steel Inst. Jpn., 23 (1983), 923.

19) T. Watanabe, Y. Shindou, T. Shiota, K. Yamato and S. Nomura: Int. Conf. on Zinc and Zinc Alloy Coated Steel Sheet (GALVATEGH '89), ISIJ, Tokyo, (1989), 80.

20) M. Kitayama, N. Miura and T. Azami: Trans. Iron Steel Inst. Jpn., 24 (1984), 742.

21) Y. Soshiki, K. Onizawa, A. Iida, T. Kanamaru and J. Morita: Jidosha Gijutsu, 42 (1988), 767.

22) Y. Numakura, M. Nakayama, M. Yamada, A. Fukada and
S. Konda: SAE 900509, (1990).

23) T. Morishita and Y. Serizawa: CAMP-ISIJ, 3 (1990), 386.

24) M. Yoshida, T. Ono, Y. Hishida and T. Hisatsune: CAMP-ISIJ, 3 (1990), 390.

25) S. Umino, K. Yamato, T. Ichida and T. Irie: Tetsu-toHagané, 73 (1987), S425.

26) Y. Shiobara, M. Abe and A. Okado: CAMP-ISIJ, 2 (1989), 1660

27) T. Isaki, M. Yoshida, M. Osawa and M. Higuchi: CAMPISIJ, 2 (1989), 616.

28) K. Yamato, S. Umino, A. Yasuda and T. Ichida: J. Surf. Finish. Soc. Jpn., 40 (1989), 162.

29) Y. Yamamoto, M. Shimoda, H. Kitazawa and H. Mizumori: Tetsu-lo-Hagané, 73 (1987), S1181.

30) T. Urakawa, M. Sagiyama, T. Adaniya and T. Hara: Tetsu-to-Hagané, 71 (1985), S1260; Trans. Iron Steel Inst. Jpn., 26 (1986), B68.

31) K. Ito, A. Iida, A. Morita, Y. Hirose and Y. Kusanagi: SAE 871206, (1987).

32) H. Nishimoto, M. Ikeda, J. Kawafuku, M. Toyama and H. Sato: CAMP-ISIJ, 1 (1988), 1631.

33) Y. Miyoshi, T. Azami, T. Nakajima, Y. Yoshida and K. Kuwano: Shikizai, 3B-13 (1987), 202

34) K. Nishimura, N. Fukuda, A. Torao, H. Uchida, M. Nagaoka and S. Koseki: CAMP-ISIJ, 3 (1990), 653.

35) H. Endoh, M. Ejima and Y. Zama: SAE 890708, (1989).

36) T. Azami, Y. Miyoshi, M. Ejima, A. Fukada and S. Shibata: CAMP-ISIJ, 2 (1989), 1686.

37) M. Nakazawa and Y. Miyoshi: J. Adh. Soc. Jpn., 25 (1989), 306. 